\title{
New Records of Bloodsucking Flies Associated with Wild Birds of Haftad- Gholleh Protected Area, Iran (Diptera: Hippoboscidae, Calliphoridae)
}

\section{Araghi $\mathrm{MP}^{1 *}$, Gilasian $\mathrm{E}^{1}$ and Samaie $\mathrm{A}^{2}$}

${ }^{1}$ Insect Taxonomy Research Department, Iranian Research Institute of Plant Protection, Agricultural Research, Education and Extension Organization (AREEO), Tehran, Iran ${ }^{2}$ Department of Environment of Markazi province, Arak, Iran

\begin{abstract}
We have studied the parasitic flies of wildlife of Haftad-Gholleh Protected Area, Iran, for the first time and report here the three hematophagous fly species of birds: the louse fly Ornithophila metallica (Schiner) (Hippoboscidae), and bird nest flies Trypocalliphora braueri (Hendel) and Protocalliphora azurea (Fallen) (Calliphoridae). The genera and species $O$. metallica and T. braueri are new to Iran.
\end{abstract}

Keywords: Avian myiasis; Louse flies; Ornithophila metallica; Trypocalliphora braueri; Protocalliphora azurea; Blow flies

\section{Introduction}

Avian myiasis-causing flies and bird's blood-feeding ectoparasite flies mainly belong in the family's Calliphoridae and Hippoboscidae. The family Hippoboscidae, commonly known as louse flies, consists of 213 hematophagous species of birds and mammals worldwide [1]. This family is known in Iran only by the single species Pseudolynchia canariensis (Macquart), pigeon fly that has been repeatedly recorded from various cities across the country [2-5]. Aside from being a nuisance to their hosts, hippoboscids are capable transmitters of pathogenic and parasitic agents, including avian trypanosomes and mammals' bacteria, causing serious diseases in wild birds [6] and ruminant animals $[7,8]$. They are also the only known vectors of apicomplexan parasites of the genus Haemoproteus to birds and transmitters of filarial nematodes to domestic and wild mammals $[9,10]$.

The majority of myiasis-inducing species belong to the family Calliphoridae, esp. subfamily Chrysomyinae, whose members are known as important facultative and obligatory parasites. Bird myiasis records are not as frequent as mammals' most likely due to the inaccessibility of the hosts. With respect to Iran, the reports of avian myiases have been poorly documented [11,12], mainly because of difficulties in larval identification. Although the said technical problem often necessitates the rearing of the maggots for a reliable identification at adult stage, in a recent case of avian wound myiasis in southwestern Iran the myiatic agent was successfully identified at larval stage [13]. The genera Protocalliphora Hough and Trypocalliphora Peus contain specialist bird nest parasites whose larvae feed on the blood of nestling birds through tunneling under their skin, causing a type of myiasis called subcutaneous myiasis, and eventually leading to heavy damages to the tissues or death of young birds [14]. The species $P$. azurea (Fallen) is widely spread in the Palaearctic region and remains the only species of birds' subcutaneous myiasis agents that has been recorded from Iran so far [15].

\section{Material and Methods}

Haftad-Gholleh Protected Area covers an estimated area of 97,400 hectares $(240,680$ acres) and is home to a large number of vulnerable mammal and bird species (Figure 1). Using Malaise traps, the specimens were collected in $75 \%$ ethyl alcohol and preserved at the Hayk Mirzayans Insect Museum (HMIM), Tehran, Iran. In case of the examination of male genitalia, we detached the whole abdomen to clear it in hot $10 \% \mathrm{KOH}$ and then washed it lightly in glacial acetic acid

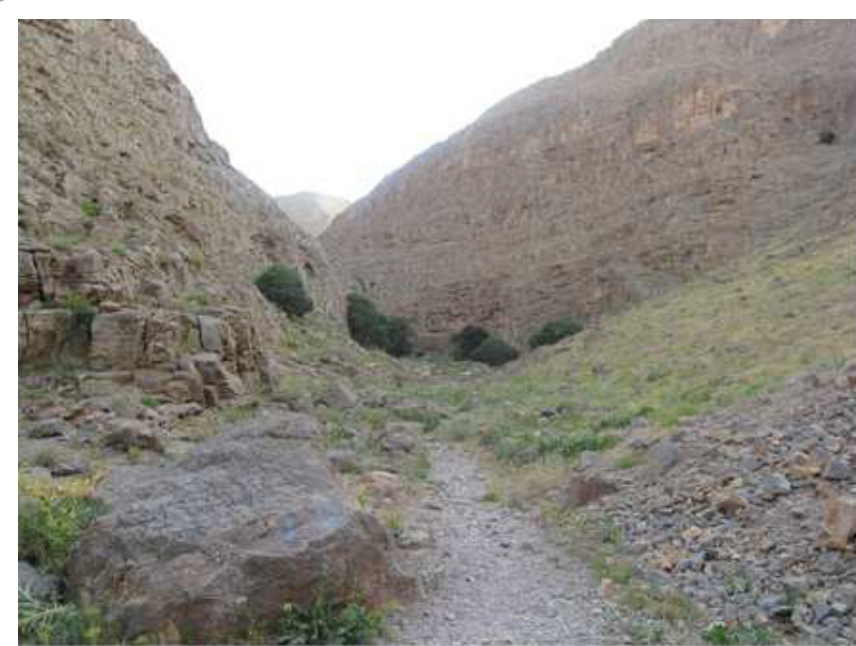

Figure 1: A general view of Chekab valley, Haftad-Gholleh protected area, Iran.

to remove the base. After dissecting the male genitalia, the abdomen was glued back to its original place and the genitalia transferred to a microvial and pinned below the associate specimen.

Specimen data: $1 \hat{\sigma} 1$ 우 Ornithophila metallica; $2 \hat{\widehat{\partial}} \hat{0} 3$ 우 Protocalliphora azurea; 1 + Trypocalliphora braueri; Iran: Markazi province, Amr-abad village, Haftad-Gholleh Protected Area, Chekab

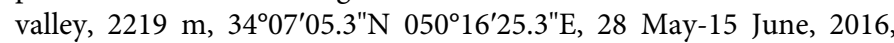
Malaise trap near pool, E. Gilasian \& M. Parchami-Araghi.

\section{Birds of haftad-gholleh protected area}

Hafted-Gholleh is home to an estimated 71 species within 26

*Corresponding author: Mehrdad Parchami Araghi, Insect Taxonomy Research Department, Iranian Research Institute of Plant Protection, Agricultural Research, Education and Extension Organization (AREEO), 19395-1454, Tehran, Iran, Tel: +982122403012; E-mail: maraghi20@yahoo.ca

Received February 15, 2017; Accepted March 02, 2017; Published March 09, 2017

Citation: Araghi MP, Gilasian E, Samaie A (2017) New Records of Bloodsucking Flies Associated with Wild Birds of Haftad-Gholleh Protected Area, Iran (Diptera: Hippoboscidae, Calliphoridae). J Biodivers Endanger Species 5: 184. doi: 10.4172/2332-2543.1000184

Copyright: (c) 2017 Araghi MP, et al. This is an open-access article distributed under the terms of the Creative Commons Attribution License, which permits unrestricted use, distribution, and reproduction in any medium, provided the original author and source are credited. 
Citation: Araghi MP, Gilasian E, Samaie A (2017) New Records of Bloodsucking Flies Associated with Wild Birds of Haftad-Gholleh Protected Area, Iran (Diptera: Hippoboscidae, Calliphoridae). J Biodivers Endanger Species 5: 184. doi: 10.4172/2332-2543.1000184

families of wild birds and serves as a sanctuary for a number of migrating birds as well. We have listed the following common avian taxa of this area to underline the impact of hematophagous flies on the bird fauna: Monticola solitarius (L.) (blue rock thrush), Accipiter spp. (hawks), Falco spp. (falcons and kestrels), Coturnix spp. (quails), Columba spp. (pigeons), Cuculus spp. (cuckoos), Coracias spp. (rollers), Merops spp. (bee-eaters), Upupa spp. (hoopoes), Galerida spp. (larks), Hirundo spp. (passerines), Muscicapa striata (Pallas) (spotted flycatcher), Emberiza melanocephala Scopoli (black-headed bunting), E. cia (L.) (rock bunting), E. citrinella L. (yellowhammer), Turdus spp. (true thrushes), Motacilla spp. (wagtails), Lanius spp. (typical shrikes), Parus spp. (tits), Passer spp. (sparrows.), Sturnus spp. (starlings), Corvus spp. (crows), Pica pica (L.) (Eurasian magpie), Ammoperdix spp. (partridges), Gypaetus spp. (vultures), Aquila spp. (eagles), Athene noctua (Scopoli) (little owl), swifts (Apodidae) and woodpeckers (Picidae) [16].

\section{Results and Discussion}

We, for the first time, collected three species of bloodsucking flies from Haftad-Gholleh Protected Area where strictly feed on wild birds. The recorded fly species are as follows: Ornithophila metallica (Schiner), Protocalliphora azurea (Fallen) and Trypocalliphora braueri (Hendel). Both O. metallica and T. braueri are new genus and species records for the Iranian fauna.

\section{Ornithophila metallica (Schiner)}

Both sexes of the hippoboscid O. metallica are hematophagous ectoparasites and ingest blood from a wide variety of birds (Figures 2 and 3). Maa [17] listed the host birds for the two Palaearctic members of Ornithophila Rondani, O. metallica and O. gestroi Rondani, and categorized the former as a species with "having high population density and very wide host and distributional ranges" and found the latter to be a species with "low population density and much more restricted host/ or distributional ranges." O. metallica is widely distributed in the Old World including Iran's neighboring countries of Pakistan, Afghanistan and Turkey (Figures 4-10) [17].

These species are commonly known as bird blow flies or bird nest flies. Trypocalliphora is a monotypic genus, with a single Holarctic

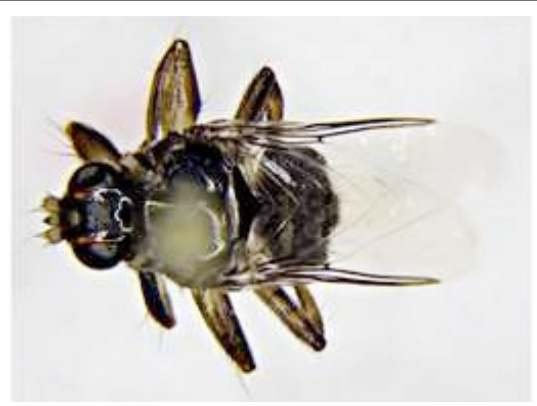

Figure 2: Ornithophila metallica (Schiner): Dorsal view.

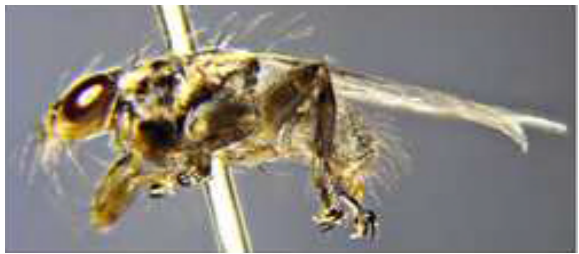

Figure 3: Ornithophila metallica (Schiner): Lateral view. species T. braueri which differs from its closest related genus Protocalliphora in having additional notopleural setae. Although some Dipterists consider Trypocalliphora a subgenus within Protocalliphora [18], other calliphorid taxonomists argued that Trypocalliphora is to be considered as a valid genus [19-21]. These species display different types of parasitic strategies as the larvae of $P$. azurea feed on the blood of young birds of the order Coraciiformes and remain on the surface of the birds, but the hematophagous larvae of T. braueri infest nestlings of the order Falconiformes and burrow beneath the skin of their hosts, causing a form of parasitism called subcutaneous myiasis [18].

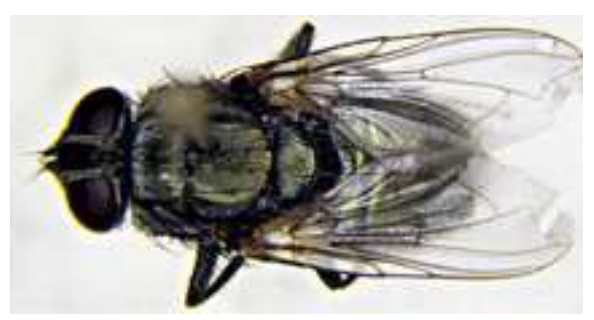

Figure 4: Protocalliphora azurea (Fallen): Dorsal view.

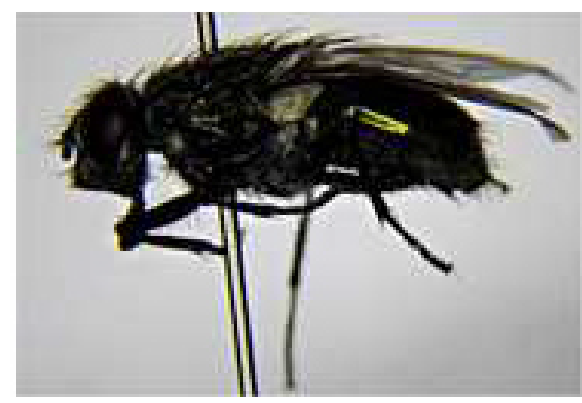

Figure 5: Protocalliphora azurea (Fallen): Lateral view.

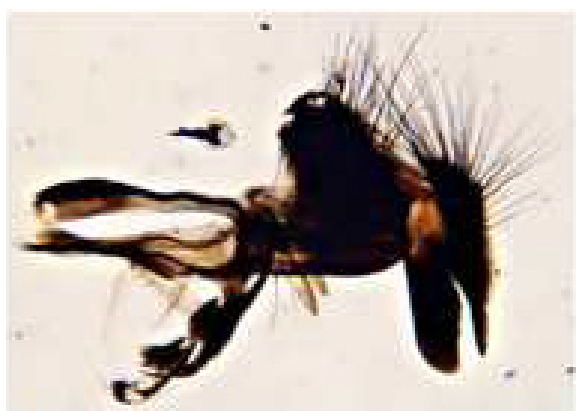

Figure 6: Protocalliphora azurea (Fallen): Male genitalia, lateral view.

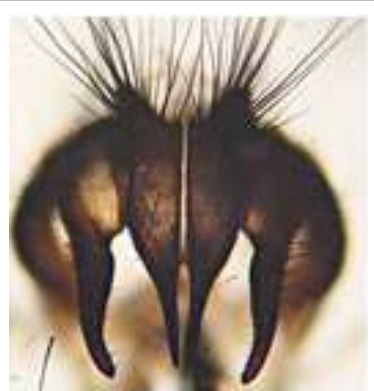

Figure 7: Protocalliphora azurea (Fallen): Male genitalia, posterior view. 
Citation: Araghi MP, Gilasian E, Samaie A (2017) New Records of Bloodsucking Flies Associated with Wild Birds of Haftad-Gholleh Protected Area, Iran (Diptera: Hippoboscidae, Calliphoridae). J Biodivers Endanger Species 5: 184. doi: 10.4172/2332-2543.1000184

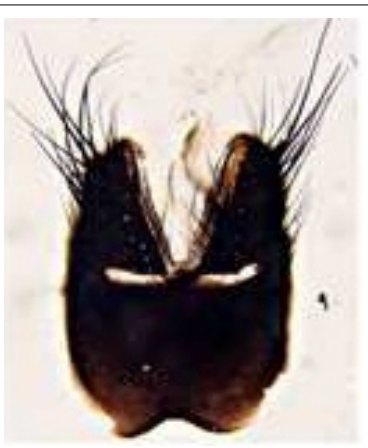

Figure 8: Protocalliphora azurea (Fallen): Male sternite.

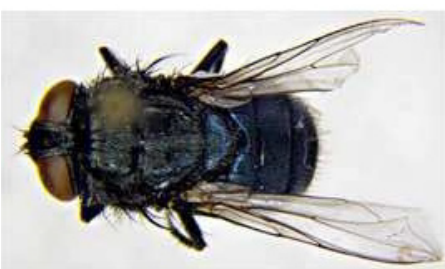

Figure 9: Trypocalliphora braueri (Hendel): Dorsal view.

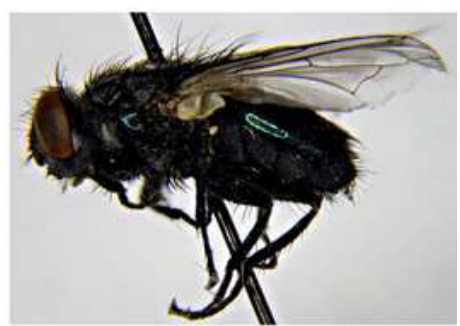

Figure 10: Trypocalliphora braueri (Hendel): Lateral view.

\section{Conclusion}

Haftad-Gholleh Protected Area, like most of Iranian natural habitats, has been experiencing destructive interventions from illegal human activities, including poaching, that aggravating the vulnerability of its wildlife to epidemics and parasites as an ovine rinderpest epidemic heavily emaciated the population of wild goats of this area in 2015. In terms of birds, the sprawling build-up areas, power lines and transmission towers pose significant threats to migrating birds of the area and nearby parks. In a framework of a faunistic project, we are working to document the insect diversity of Haftad-Gholleh Protected Area to underscore the need for improving the conservation measures and policies towards a standard protection of the area and its fauna and flora.

\section{Acknowledgements}

We wish to thank Dr Nil Rahola (Université de Montpellier, Montpellier, France) for confirming the identity of Ornithophila metallica. We are also gratefu to the Department of Environment of Markazi province and the rangers at HaftadGholleh Protected Area for facilitating our research through the area.

\section{References}

1. Dick CW (2006) Checklist of world Hippoboscidae (Diptera: Hippoboscoidea). Department of Zoology, Field Museum of Natural History, Chicago p: 7.

2. Borji H, Moghaddas E, Razmi GR, Azad M (2012) A survey of ecto-and endoparasites of domestic pigeons (Columba livia) in Mashhad, Iran. Iran J Vet Sci Technol 4: 37-42.
3. Radfar MH, Fathi S, Norouzi AE, Mirzaei DM, Rezaei SH (2011) A survey of parasites of domestic pigeons (Columba livia domestica) in South Khorasan, Iran. Vet Res 4: 18-23.

4. Pirali KK, Dehghani SA, Ahmadi BN, Najafzadeh V (2016) A First report of infestation by Pseudolynchia canariensis in a herd of pigeons in Shahrekord (Southwest of Iran). J Arthropod-Borne Dis 10: 426-430.

5. Khoobdel M, Akhoond MR (2015) The survey on Pseudolynchia canariensis (Diptera: Hippoboscidae) in military sites and human bite cases reported in Tehran, Iran. J Milit Med 16: 243-251.

6. Kucera J (1983) Incidence and some ecological aspects of avian trypanosomes in Czechoslovakia. Folia Parasitol 30: 209-222.

7. Halos L, Jamal T, Maillard R, Girard B, Guillot J, et al. (2004) Role of Hippoboscidae flies as potential vectors of Bartonella spp. infecting wild and domestic ruminants. Appl Environ Microbiol 70: 6302-6305.

8. Reeves WK, Nelder MP, Cobb KD, Dasch GA (2006) Bartonella spp. in dee keds, Lipoptena mazamae (Diptera: Hippoboscidae), from Georgia and South Carolina, USA. J Wildlife Dis 42: 391-396.

9. Nelson GS (1963) Dipetalonema dracunculoides (Cobbold, 1870), from the dog in Kenya: with a note on its development in the lousefly, Hippobosca longipennis. J Helminthol 37: 235-240.

10. Daynes P (1964) Note sur les helminthoses des animaux domestiques reconnues à Madagascar. Revue d'Élevage et de Médecine Vétérinaire des Pays Tropicaux 17: 477-490

11. Halajian A, Tavakol S, Mansoori J (2012) The first report of pigeon maggot Protocalliphora sp. (Diptera: Calliphoridae) from domestic pigeons in Iran. Comp Clin Pathol 21: 361-362.

12. Pirali KK, Cheraghchi BM, Navidpour S (2010) Infestation of an owl (Bubo bubo) with Lucilia spp. Comp Clin Pathol 19: 221-2214

13. Parchami AM, Eskandari F, Gilasian E (2015) Avian wound myiasis caused by Calliphora vicina Robineau Desvoidy (Diptera: Calliphoridae) in an immature migrating Eastern Imperial Eagle (Aquila heliaca Savigny) (Aves: Accipitridae) in southwestern Iran. Vet Sci Technol 6

14. Little SE (2009) Myiasis in wild birds. Parasitic Diseases of Wild Birds. In: Atkinson CT, Thomas NJ, Hunter DB (ed.) Wiley-Blackwell, Oxford pp: 546-556.

15. Parchami AM, Peris SV, Gonzalez MD (2001) New records of Iranian Calliphoridae and Sarcophagidae, with a guide to the males of Palaearctic Protocalliphora (Diptera, Calyptratae). Boletín de la Real Sociedad Española de Historia Natural (Sección Biológica) 96: 175-181.

16. (2003) Reports of wildlife of Hafta-Gholleh Protected Area.

17. Maa TC (1969) Synapses of the genera Ornithophila and Ornithoctona with remarks on their habitat diversification (Diptera: Hippoboscidae). Pacific Insects Monograph 20: 1-23.

18. Sabrosky CW, Bennett GF, Whitworth TL (1989) Bird blow flies (Protocalliphora) in North America (Diptera: Calliphoridae) with notes on the Palearctic species. Smithsonian Institution, Washington, DC, USA.

19. Rognes K (1985) Revision of the bird-parasitic blowfly genus Trypocalliphora Peus, 1960 (Diptera: Calliphoridae). Entomologica Scandinavica 15: 371-382.

20. Whitworth TL (2003) A key to the puparia of 27 species of North American Protocalliphora Hough (Dipetera: Calliphoridae) from bird nests and two new puparial descriptions. Proc Entomol Soc Wash 105: 995-1033.

21. Whitworth TL (2006) Key to the genera and species of blow flies (Diptera: Calliphoridae) of America north of Mexico. Proc Entomol Soc Wash 108: 689-725. 